\title{
EDITORIAL
}

\section{In This Issue: Risk and Care Management}

\author{
Kurt C. Stange, $M D, P b D$, Editor
}

Ann Fam Med 2007;5:386. DOI: 10.1370/afm.771.

T he articles in this issue develop 2 themes: risk assessment and care management.

The risks identified in these studies relate to anger and the progression of prehypertension to hypertension and coronary heart disease, ${ }_{1}^{1}$ development of diabetes among young adults, ${ }^{2}$ suicide risk assessment among standardized patients portraying either major depression or adjustment disorder, ${ }^{3}$ and risk for domestic violence. ${ }^{4}$

Two systematic reviews examine both risk and clinical management. One identifies racial differences in the efficacy of antihypertensive therapy. ${ }^{5}$ The other assesses differences in international guidelines for management of acute sore throat. ${ }^{6}$

Several other studies inform our clinical management of patients. For example, Bayliss and colleagues discover barriers to self-management of chronic diseases, many of which are mutable.

Howard and colleagues ${ }^{8}$ find that among 1,245 patients of 36 practices in Thunder Bay, Ontario, patient satisfaction with after-hours care of an urgent problem is higher if provided by patients' own family physician or their physician's after-hours clinic, compared with a walk-in clinic, the emergency department, and telephone health advisory services. This study can inform the proliferation of less personal sources of after-hours care in many countries.

A clinical trial of a 6 -hour vs 2 -hour continuing education intervention finds varied effects on communication with patients with breast cancer. ${ }^{9}$

Two essays propose innovative staffing models for making feasible the growing opportunities in management of chronic illness in patients. ${ }^{10,11}$ We feature these articles together in the Annals Journal Club, ${ }^{12}$ and encourage creative discussion about health care reform at both the system and practice level that could enable these and other innovations.

With this issue, the Annals welcomes the College of Family Physicians of Canada as a new sponsoring organization. We are delighted by the CFPC's show of sup- port for our mission of advancing knowledge essential to understanding and improving health and primary care. As always, we are honored by the many collaborative efforts that make the Annals possible.

Please share your insights by joining the Annals online discussion at http://www.AnnFamMed.org.

To read or post commentaries in response to this article, see it online at http://www.annfammed.org/cgi/content/full/5/5/386.

\section{References}

1. Player MS, King DE, Mainous AG III, Geesey ME. Psychosocial factors and progression from prehypertension to hypertension or coronary heart disease. Ann Fam Med. 2007;5(5):403-411.

2. Mainous AG III, Diaz VA, Everett CJ. Assessing risk for development of diabetes in young adults. Ann Fam Med. 2007;5(5):425-429.

3. Feldman MD, Franks P, Duberstein PR, Vannoy S, Epstein R, Kravitz RL. Let's not talk about it: suicide inquiry in primary care. Ann Fam Med. 2007;5(5):412-418.

4. Chen PH, Rovi S, Washington J, et al. Randomized comparison of 3 methods to screen for domestic violence in family practice. Ann Fam Med. 2007;5(5):430-435.

5. Park IU, Taylor AL. Race and ethnicity in trials of antihypertensive therapy to prevent cardiovascular outcomes: a systematic review. Ann Fam Med. 2007;5(5):444-452.

6. Matthys J, De Meyere M, van Driel ML, De Sutter A. Differences among international pharyngitis guidelines: not just academic. Ann Fam Med. 2007;5(5):436-443.

7. Bayliss EA, Ellis JL, Steiner JF. Barriers to self-management and quality-of-life outcomes in seniors with multimorbidities. Ann Fam Med. 2007;5(5):395-402.

8. Howard M, Goertzen J, Hutchinson B, Kaczorowski J, Morris K. Patient satisfaction with care for urgent health problems: a survey of family practice patients. Ann Fam Med. 2007;5(5):419-424.

9. Stewart M, Brown JB, Hammerton J, et al. Improving communication between doctors and breast cancer patients. Ann Fam Med. 2007;5(5):387-394

10. Zweifler J. The missing link: improving quality with a chronic disease management intervention for the primary care office. Ann Fam Med. 2007;5(5):453-456.

11. Bodenheimer T, Laing BY. The teamlet model of primary care. Ann Fam Med. 2007;5(5):457-461.

12. Stange KC. Annals Journal Club: novel staffing for improved patient disease management. Ann Fam Med. 2007;5(5):iii. 